\title{
Tadabbur Surat Al-Insyirah untuk Menurunkan Stres Akademik Mahasiswa
}

\author{
Eko Hardi Ansyah ${ }^{1}$, Hindun Muassamah ${ }^{2}$, Cholichul Hadi ${ }^{3}$ \\ ${ }^{1,2}$ Universitas Muhammadiyah Sidoarjo \\ ${ }^{3}$ Universitas Airlangga Surabaya \\ 1 e-mail: ekohardiansyah@umsida.ac.id
}

\begin{tabular}{|c|c|}
\hline Abstract / Abstrak & Keywords / Kata kunci \\
\hline $\begin{array}{l}\text { The purpose of this research is to examine the effect of Al-Insyirah contemplation } \\
\text { to reduce the academic stress level on Islamic university students. Al-Insyirah } \\
\text { contemplation is an Islamic term that related to deep contemplation and } \\
\text { visualization for the psychological aspects of the surah of Al-Insyirah. This } \\
\text { research used the pre-post experimental design. The participants were } 16 \text { students } \\
\text { who experience academic stress. Before the subjects were trained by Al-Insyirah } \\
\text { contemplation, academic stress scale was administered to measure the academic } \\
\text { stress level. Then Al-Insyirah contemplation were trained to them, which consists } \\
\text { of six steps. After two weeks, the academic stress scale was measured again. The } \\
\text { result of before and after the contemplation were analysed using t-test analysis. } \\
\text { The results show that Al-Insyirah contemplation could lower the students' } \\
\text { academic stress. Consequently, students after using this contemplation are able to } \\
\text { think positively to solve various challenges and difficulties in campus life. }\end{array}$ & $\begin{array}{l}\text { Contemplation Training } \\
\text { Al-Insyirah letter } \\
\text { Holy Quran } \\
\text { Academic Stress }\end{array}$ \\
\hline $\begin{array}{l}\text { Tujuan dari penelitian ini adalah menguji pengaruh dibacakannya surat } \\
\text { Al-Insyirah untuk mengurangi stres akademik pada mahasiswa Islam. } \\
\text { Pembacaan Al-Insyirah ini berkaitan dengan aspek-aspek psikologis } \\
\text { individu. Studi dilakukan dengan desain eksperimental pre-post. Subjek } \\
\text { terdiri dari } 16 \text { pelajar yang mengalami stres akademik. Sebelum diberikan } \\
\text { Al-Insyirah, diukur terlebih dahulu level stres akademik menggunakan } \\
\text { skala stres akademik. Eksperimen dilakukan melalui enam tahapan. } \\
\text { Setelah dua minggu, stres akademik diukur kembali. Hasil sebelum dan } \\
\text { sesudah perlakuan diukur dengan analisis } t \text { Test. Hasil studi menunjukkan } \\
\text { bahwa pembacaan surat Al-Insyirah dapat menurunkan stres akademik } \\
\text { sehingga menjadi rekomendasi bagi seorang pelajar untuk menghadapi } \\
\text { tantangan dan kesulitan di kampus dengan sikap dan pikiran positif. }\end{array}$ & $\begin{array}{l}\text { Pelatihan Kontemplasi } \\
\text { Surat Al-Insyirah } \\
\text { Stres Akademik } \\
\text { Al-quran }\end{array}$ \\
\hline
\end{tabular}

\section{Pendahuluan}

Dalam sebuah institusi pendidikan Kualitas mahasiswa menjadi sebuah aspek penting. Bekalnya adalah penguasaan akademik, hard skill dan soft skill. Dengan demikian, mahasiswa akan mampu menempuh dunia pekerjaan dan terjun di lingkungan sosial masyarakat. Untuk mencapai tujuan tersebut mahasiswa akan dihadapkan dengan rutinitas kehidupan akademik seperti menghadiri perkuliahan, menyelesaikan tugas, pengabdian pada masyarakat, penelitian, ujian dan skripsi sebagai syarat kelulusan.

Robothom (2008), mengatakan bahwa dalam menyelesaikan akademiknya mahasiswa dihadapkan pada beberapa situasi yang menyulitkan. Diantaranya adalah kondisi ujian, adaptasi terhadap kehidupan perkuliahan, kondisi perbedaan bahasa yang digunakan dan masalah finansial. Mahasiswa juga dituntut untuk beradaptasi terhadap sistem pembelajaran yang berbeda dengan sistem pembelajaran yang diterima di sekolah menengah atas. Sistem pembelajaran di perguruan tinggi menuntut mahasiswa untuk aktif dan mandiri karena kontrol dan pengawasan pembelajaran berada ditangan mahasiswa itu sendiri. Kehidupan akademik dan sistem pembelajaran yang berbeda di perguruan tinggi dapat menimbulkan tekanan tersendiri bagi mahasiswa. Menurut Giordano (2005), perubahan dan tekanan akan 
menimbulkan stres dan memaksa individu untuk beradaptasi.

Studi literatur mengenai stres pada mahasiswa cenderung tinggi. Stres yang paling umum dialami oleh mahasiswa merupakan stres akademik. Jumlah mahasiswa yang mengalami stres akademik meningkat setiap semester (Govaerst \& Gregoire, 2004). Hal ini sesuai dengan hasil penelitian Kohn dan Frazer (dalam Rathakrishnan, 2009) yang menyatakan bahwa pelajar universitas sering berhadapan dengan stress akademik dalam menjalani kehidupan di kampus seperti, beban tugas yang diberikan oleh dosen, situasi yang tertekan, masalah penyesuaian, konflik dan persaingan dalam pencapaian akademik. Selain itu karena persoalan bahasa (Murphy dan Kandil, 2003), tuntutan untuk mendapatkan nilai akademik yang tinggi, terlalu banyak tugas, kompetisi dengan mahasiswa lain, kegagalan dan hubungan buruk dengan mahasiswa atau dosen, dan tuntutan untuk mendapatkan Indeks Prestasi Kumulatif (IPK) yang tinggi.

Govaerst \& Gregoire (2004), menyatakan bahwa stres akademik diartikan sebagai hasil persepsi dan penilaian tentang stresor akademik yang memunculkan tekanan pada individu yang berhubungan dengan pendidikan dan ilmu pengetahuan di perguruan tinggi. Stres akademik merupakan stres yang terjadi karena stresor akademik. Academic stressor yaitu stres mahasiswa yang ditimbulkan karena proses belajar mengajar atau hal-hal yang berhubungan dengan kegiatan belajar. Hal tersebut meliputi, yaitu tekanan untuk naik tingkat, lama belajar, banyak tugas, mendapat nilai ulangan, birokrasi, mendapatkan beasiswa, keputusan menentukan jurusan dan karir serta kecemasan ujian dan manajemen waktu. Hal ini seharusnya bisa segera diselesaikan oleh mahasiswa, karena stres yang berlangsung cukup lama, akan membuat tubuh berusaha mengadakan penyesuaian sehingga bisa menimbulkan perubahan patologis bagi penderitanya (Hawari, 2005).

Manifestasi aspek stres akademik terwujud dalam empat aspek, yaitu manifestasi kognitif dimana stres akademik dapat mempengaruhi penurunan fungsi berfikir seperti sulit berkonsentrasi dan mudah lupa. Manifestasi Psikologis, biasanya lebih dikaitkan pada aspek emosi yang tidak menyenangkan seperti, khawatir mudah marah / sensitif, kecewa, tertekan dan merasa tidak berharga. Manifestasi Fisiologis dari stres akademik adalah terganggunya pola-pola normal dari aktivitas fisiologis yang ada, biasanya muncul dalam bentuk keluhan fisik, seperti pusing atau sakit kepala gemetar, pola makan tidak teratur dan pola tidur tidak teratur. Manifestasi aspek perilaku, dapat berarti bahwa dalam kondisi stres individu dapat menunjukkan perilakuperilaku negatif dan menarik diri dari lingkungan sosial sebagai manifestasi dari ketidakberdayaan individu dalam menghadapi tekanan yang berat dan mengancam, seperti menyendiri dan menarik diri dari pergaulan dan menunda menyelesaikan tugas kuliah (Safaria \& Saputra, 2007).

Manifestasi dari stres akademik tersebut akan memengaruhi mahasiswa secara keseluruhan yaitu dari fungsi kognitif, psikologis, fisiologis dan perilaku, yang dapat menyebabkan produktivitas mahasiswa kurang optimal. Stres yang berkepanjangan yang dialami oleh individu dapat mengakibatkan penurunan kemampuan untuk beradaptasi terhadap stres (Potter \& Perry, 2005). Stres akademik dapat berdampak positif atau negatif (Agolla \& Ongori, 2009). Dampak positif dari stres, membantu individu untuk tetap aktif dan waspada, selama stres yang dialami masih dalam batas kapasitas individu. Hal ini bertentangan dengan hasil penelitian yang dilakukan Barram dalam Muhammad (2011), menunjukkan stres jangka pendek yang berlangsung hanya beberapa jam saja dapat menyebabkan kerusakan di daerah otak hippocampus, sehingga struktur otak penting yang berhubungan dengan memori deklaratif dan fakta tidak bisa memberikan fungsi yang semestinya, sehingga terjadi lupa. Saat stres molekul Corticotropin Releasing Hormones $(\mathrm{CRH})$ menjadi aktif, sehingga mengganggu proses cara otak dalam mengumpulkan dan menyimpan ingatan. 
Penelitian yang dilakukan Goff (2011) menyatakan bahwa meningkatnya stres akademik bisa berpengaruh pada menurunnya kemampuan akademik yang yang berimlikasi pada terhadap indeks prestasi yang rendah. Goff (2011) menunjukkan bahwa beban stres yang dirasa terlalu berat oleh mahasiswa dapat memicu gangguan memori, konsentrasi, penurunan kemampuan penyelesaian masalah, dan kemampuan akademik. Selain itu, dapat memicu individu untuk berperilaku negatif, seperti merokok, penggunaan alkhohol, tawuran, seks bebas bahkan penyalahgunaan NAPZA (Widianti, 2007). Penelitian Weidner, dkk.,(1996 dalam Widianti, 2007) menunjukkan pengaruh stres akademik terhadap perilaku kesehatan pada mahasiswa, bahwa mahasiswa yang mengalami stres akademik yang tinggi mengalami penurunan dalam menjaga kesehatannya antara lain, malas dalam melakukan perawatan diri, malas dalam melakukan olah raga, rentan terhadap penggunaan narkoba, dan melakukan pola makan yang tidak sehat. Kondisi lelah (fatigue) akibat stres akademik mengakibatkan turunnya produktifitas dalam belajar maupun aktifitas pribadi (Wulandari, 2012). Oleh karena itu diperlukan koping yang efektif untuk menurunkan tingkat stres akademik pada mahasiswa. Salah satu koping tersebut adalah coping dengan pendekatan religius. Penggunaan pendekatan religius perlu dilakukan berdasarkan perlunya layanan kesehatan mental yang sesuai dengan kelompok klien (Sabry \& Vohra, 2013). Dimana saat ini, jumlah penduduk muslim di Indonesia mendominasi dengan jumlah $87 \%$ dari 238 juta penduduk menurut sensus penduduk 2010 (Yusuf, 2015). Sabry \& Vohra (2013) juga mempertegas bahwa integrasi antara spiritualitas dan religiusitas kedalam psikoterapi dan keyakinan religius mempengaruhi rencana manajemen. Karena itu, peneliti meyakini pentingnya untuk menggunakan tadabbur surat Al-Insyirah sebagai pendekatan untuk mengurangi stress akademik tersebut. Hal ini juga didukung oleh pendapat Ansyah dan Hadi (2017) yang menggunakan Al-Fatihah sebagai basis konsep untuk melakukan intervensi psikologi.

Hayyi (2012) menyatakan bahwa tadabbur Al-Quran adalah perenungan yang menyeluruh untuk mengetahui maksud dan makna dari suatu ayat atau surat dalam al-quran secara mendalam. Tadabbur adalah berfikir secara menyeluruh yang sampai pada akhir-akhir dari indikasi-indikasi kalimat dan tujuan-tujuannya yang jauh. Sedangkan Makna tadabbur AlQur'an adalah berfikir dan memperhatikan ayat-ayat Al-Qur'an untuk memahaminya, mengetahui makna-maknanya, hikmahhikmahnya, dan maksudnya untuk dijadikan ibrah atau pelajaran.

Tadabbur Surat Al-insyirah adalah salah satu metode berinteraksi dengan Al-Quran dengan cara membaca secara tartil, menghayati dan memahami arti kemudian melakukan perenungan dan pencermatan ayat-ayat yang ada dalam surat Al-Insyirah untuk tujuan dipahami, diketahui makna-maknanya, hikmah serta maksudnya kemudian dijadikan tuntunan dalam menjalani kehidupan. Surat Al-Insyirah dijadikan Allah SWT sebagai perumpamaan untuk menggambarkan masalah yang dihadapi manusia dengan memakai prinsip mekanika beban (Hasan, 2008). Lebih lanjut menurut Hasan (2008) surat Al-insyirah telah dipergunakan untuk menggambarkan stres yang jelas yaitu menggunakan kata beban (pada punggung) untuk menggambarkan masalah berat yang dihadapi manusia."Dan Kami telah menghilangkan daripada-mu (Muhammad) bebanmu. Yang memberatkan punggungmu (Qs.Al-inyirah: 1-3). Ayat ini, dalam pemaparannya, telah menggunakan pemisalan dari prinsip mekanika beban, dimana punggung merupakan daerah yang mendapatkan tenaga. Daerah yang mendapatkan tenaga, dalam prinsip mekanika beban disebut stres (Hasan, 2008). Dalam surat Al-Insyirah juga terdapat solusi untuk menghadapi stres yaitu dengan memahami, menghayati dan melakukan visualisasi dengan aspek-aspek psikologis dari surat Al-Insyirah yaitu sabar, optimis, ketenangan jiwa, percaya pada kemampuan diri dan tawakal (Juriyah, 2012). 
Pelatihan tadabbur Surat Al-Insyirah ditujukan untuk mengubah pikiran-pikiran negatif mahasiswa sebagai akibat dari stres akademik. Pikiran negatif dapat memunculkan perasaan dan perilaku yang negatif pula, sehingga dapat mengakibatkan penurunan produktivitas dan memberikan pengaruh negatif pada kesehatan (Hasan, 2008). Dengan mengerti, memahami, memaknai, menghayati, dan mengambil ibrah dari isi surat al-Insyirah, individu diharapkan dapat mengubah pola pikir yang negatif kearah yang positif. Melalui pelatihan tadabbur surat Al-Insyirah mahasiswa dibimbing untuk berpikir dan berperilaku positif dengan menanamkan makna dan isi yang terkandung dalam surat tersebut. Aspek-aspek psikologis tersebut didiskusikan untuk memberikan korelasi positif terhadap permasalahan yang dihadapi mahasiswa yaitu stres akademik. Pikiran-pikiran negatif yang timbul karena stres akademik diganti dengan pikiran-pikiran positif melalui penghayatan yang mendalam tentang aspek-aspek psikologis yang terkandung dalam surat Al-Insyirah.

Beberapa studi menunjukkan bahwa berpikir postif dapat meningkatkan kesehatan fisik dan psikologis, memberikan korelasi positif terhadap proses penyembuhan penyakit dan kesejahteraan (Hasan, 2008). Berpikir positif bukan berarti mengabaikan situasi yang kurang menyenangkan atau mengabaikan sesuatu yang negatif. Berpikir positif yakni memberikan pendekatan pada setiap hal baik yang menyenangkan maupun tidak menyenangkan dengan cara yang lebih positif dan produktif. Berpikir positif juga merupakan bagian penting dari manajemen stres yang efektif (Hasan, 2008).

Lebih lanjut, Richard dan Bergin (dalam Purwoko, 2012) menyatakan bahwa ayat-ayat dalam kitab suci telah digunakan psikoterapis untuk membantu klient dalam penyembuhan stres dan kecemasan. Penelitian yang dilakukan oleh Azzahra (2012) mengenai efektivitas pelatihan pemaknaan surat Al-Insyirah untuk mengurangi stres mahasiswa yang sedang mengerjakan skripsi, menunjukkan bahwa kelompok mahasiswa yang mendapatkan pelatihan pemaknaan surat Al-Insyirah mengalami penurunan tingkat stres daripada kelompok mahasiswa yang tidak mendapatkan pelatihan pemaknaan surat Al-Insyirah. Berdasarkan permasalahan tersebut, penting kiranya untuk melakukan penelitian tentang tadabbur surat $\mathrm{Al}$-Insyirah untuk menurunkan tingkat stres akademik pada mahasiswa. Hipotesis dari penelitian ini adalah ada pengaruh pelatihan tadabbur surat Al-Insyirah untuk menurunkan tingkat stres akademik pada mahasiswa, yang menunjukkan bahwa pelatihan tadabbur surat Al-Insyirah mempunyai pengaruh yang positif untuk menurunkan tingkat stres akademik pada mahasiswa.

\section{Metode}

\section{Partisipan}

Subjek penelitian ini adalah 16 orang mahasiswa yang memenuhi kriteria sebagai berikut: tingkat stres sedang sampai tinggi, dapat membaca Al-Quran secara tartil, menguasai Bahasa Arab, telah mendapatkan mata kuliah tafsir Al-Quran, bersedia secara sukarela untuk mengikuti pelatihan tadabbur surat al-Insyirah.

\section{Instrumen Penelitian}

Instrumen dalam penelitian ini menggunakan Skala stres akademik yang dikonstruksikan sendiri oleh peneliti berdasarkan empat (4) aspek yaitu aspek kognitif, aspek fisiologis, aspek psikologis dan aspek perilaku dengan menggunakan tiga belas (13) indikator berdasarkan teori Safaria dan Saputra (2007) yaitu: sulit berkonsentrasi, mudah lupa, merasa tidak berharga, khawatir, mudah marah, cemas, tertekan, pusing, gemetar, pola makan tidak teratur, pola tidur tidak teratur, menarik diri dari pergaulan, dan menunda penyelesaian tugas. Partisipan diminta memberi respon terhadap 4 poin skala likert (1 $=$ tidak setuju hingga $4=$ sangat setuju). Konsistensi interval skala stres akademik dilihat dari koefisien reliabilitas dari Cronbach menunjukkan angka 0.922 dengan daya beda item bergerak dari 0.27 sampai 0.68 . 


\section{Prosedur}

Penelitian ini merupakan penelitian eksperimental dengan bentuk pre eksperimental design dengan model one group pretest-posttest design. Pada penelitian ini pada awal penelitian sampel dilakukan pengukuran tingkat stres akademik, kemudian dilakukan manipulasi yaitu pelatihan tadabbur surat Al-Insyirah, setelah manipulasi, dilakukan kembali pengukuran terhadap tingkat stres akademik. Pelaksanaan eksperimen dilakukan melalui beberapa tahap, yaitu persiapan pemberian pelatihan tadabbur, pemberian skala stres akademik kepada peserta sebagai pretest, pemberian perlakuan yaitu pelatihan tadabbur surat Al-Insyirah kepada sujek penelitian yang diberikan selama empat kali pertemuan mulai selama dua minggu dengan durasi masingmasing sesi 100 menit, setelah itu dilakukan postes untuk mengukur perubahan tingkat stres akademik subjek penelitian.

\section{Hasil \\ Uji t-test}

Hasil perhitungan paired-sampels t-test menggunakan bantuan program SPSS 17.0 for Windows yang dapat dilihat pada tabel dibawah ini. Berdasarkan uji statistik pada tabel tersebut, menunjukkan bahwa $t_{\text {hitung }}=14.492 ; \rho=0.000$. Jika $\rho<0.05$, maka nilai pretest dan postest pada sabjek penelitian ada perbedaan.

Pada pengujian dengan statistik diperoleh $\mathrm{t}_{\text {hitung }}=14.492>\mathrm{t}_{\text {tabel }}=2.132(\mathrm{df}=15 ; \alpha=$ $0,05)$ dengan $\rho=0,000 ; \rho<0,05$, maka dapat dijelaskan bahwa ada perbedaan yang sangat signifikan pada kelompok sabjek penelitian sebelum diberikan perlakuan dan sesudah diberikan diberikan perlakuan, untuk itu dapat disimpulkan bahwa ada pengaruh pelatihan tadabbur surat Al-Insyirah untuk menurunkan tingkat stres pada mahasiswa Mah'ad Umar Bin Al-Khatab.
Perilaku orang sabar selalu berkorelasi dengan nilai-nilai kebaikan (Kumala \& Trihandayani, 2015). Tidak ada yang melakukan kejahatan, kecuali ketika mereka tidak mampu menghadapi situasi tertentu (Najati, 2005). Muhammad Utsman Najati menjelaskan bahwa sabar sebagai bentuk kebenaran. Merupakan konsep sabar yang menjelaskan bahwa sabar terdiri dari beberapa dimensi yaitu sabar terhadap segala kewajiban yang ada, kemudian sabar terhadap segala larangan Allah Swt, dan juga sabar terhadap kebenaran atau kenyataan yang diterima dari segala sesuatu yang datang kepada manusia (Najati, 2005). Adapun hakikat kesabaran terhadap pembawaan makruhnya jiwa dan pencapaian setelah hal itu berarti kebenaran yang maknanya adalah kembali kepada Allah dengan taubat yang sebenarnya (Najati, 2005).

\section{Hasil Perhitungan Uji Univariate}

Untuk mengetahui besarnya pengaruh pelatihan tadabbur surat Al-Insyirah untuk menurunkan tingkat stres akademik menggunakan univariate. Perhitungan univariate pada penelitian ini menggunakan bantuan SPSS 17.0 for Windows. Adapun hasilnya dapat dilihat pada tabel 2.

Berdasarkan uji statistik pada tabel 2, menunjukkan bahwa $\mathrm{F}_{\text {hitung }}=179.917>\mathrm{F}_{\text {tabel }}=$ $4.49(\mathrm{df}=1 ; \mathrm{N}=16 ; \alpha=0.05)$ dengan $\mathrm{sig} / \rho=$ $0.000 ; \rho<0.05$, sehingga dapat disimpulkan bahwa ada pengaruh yang sangat besar pelatihan tadabbur Surat Al-Insyirah untuk menurunkan tingkat stres akademik. Sedangkan besar pengaruh partial eta squared $=0.857$, yang artinya bahwa besar pengaruh pelatihan tadabbur surat Al-Insyirah dalam menurunkan tingkat stres akademik pada mahasiswa putri mustawa Tsani adalah sebesar $85.7 \%$. Dari hasil perhitungan diatas dapat disimpulkan bahwa pelatihan tadabbur surat Al-Insyirah dapat menurunkan tingkat stres akademik pada mahasiswa.

\section{Diskusi}


Tabel 1

Hasil Uji t Nilai Pretest dan Postest

\begin{tabular}{|c|c|c|c|c|c|c|c|c|c|}
\hline \multicolumn{10}{|c|}{ Paired Samples Test } \\
\hline \multicolumn{10}{|c|}{ Paired Differences } \\
\hline & & & $\begin{array}{l}\text { Std. } \\
\text { Devi }\end{array}$ & Std. Error & $\begin{array}{c}95 \% \text { Conf } \\
\text { Interval } \\
\text { Differe }\end{array}$ & $\begin{array}{l}\text { idence } \\
\text { of the } \\
\text { nce }\end{array}$ & & & Sig. (2- \\
\hline & & Mean & ation & Mean & Lower & Upper & $\mathrm{t}$ & df & tailed) \\
\hline Pair 1 & $\begin{array}{l}\text { pra } \\
\text { pelatihan } \\
\text { - post } \\
\text { pelatihan }\end{array}$ & $\begin{array}{r}43.875 \\
00\end{array}$ & $\begin{array}{r}12.10 \\
991\end{array}$ & 3.02748 & 37.42208 & 50.32792 & $\begin{array}{r}14.49 \\
2\end{array}$ & 15 & .000 \\
\hline
\end{tabular}

Tabel 2

Hasil Uji Univariate

Tests of Between-Subjects Effects

Dependent Variable:Stres akademik

\begin{tabular}{|c|c|c|c|c|c|c|}
\hline Source & $\begin{array}{l}\text { Type III Sum } \\
\text { of Squares }\end{array}$ & df & Mean Square & $\mathrm{F}$ & Sig. & $\begin{array}{l}\text { Partial Eta } \\
\text { Squared }\end{array}$ \\
\hline Corrected Model & $15400.125^{\mathrm{a}}$ & 1 & 15400.125 & 179.917 & .000 & .857 \\
\hline Intercept & 371522.000 & 1 & 371522.000 & 4340.422 & .000 & .993 \\
\hline PREPOST & 15400.125 & 1 & 15400.125 & 179.917 & .000 & .857 \\
\hline Error & 2567.875 & 30 & 85.596 & & & \\
\hline Total & 389490.000 & 32 & & & & \\
\hline Corrected Total & 17968.000 & 31 & & & & \\
\hline
\end{tabular}

a. $\quad$ R Squared $=.857$ (Adjusted R Squared $=.852)$

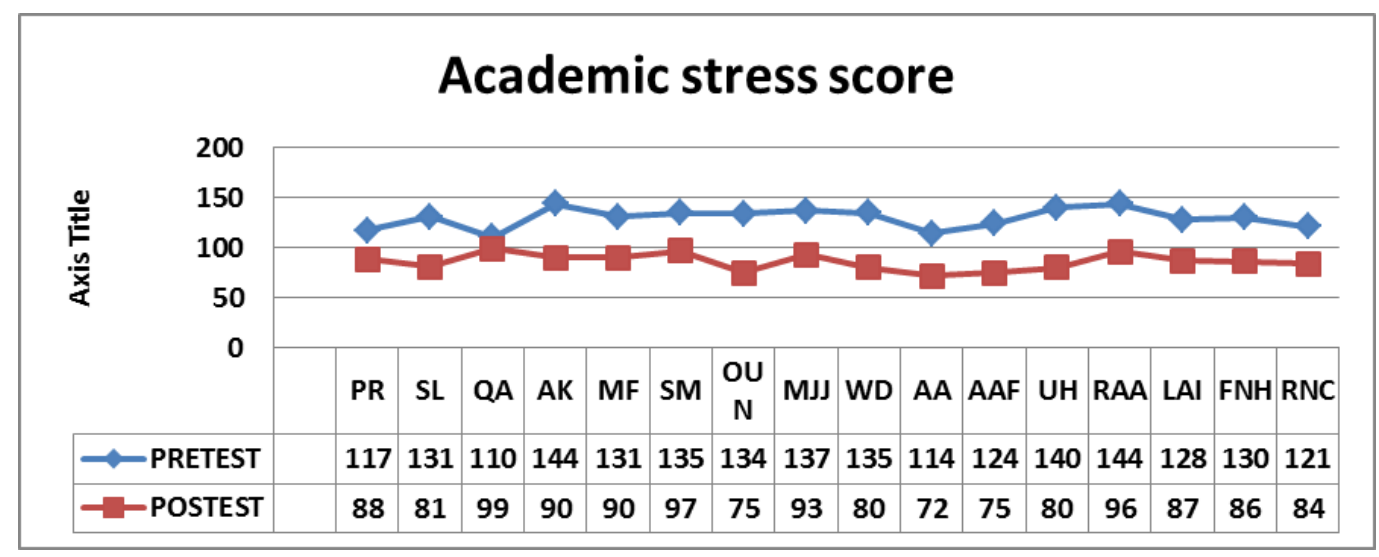

Gambar 1. Grafik Skor Tingkat Stres Pretest Dan Postest

\section{Diskusi}

Analisis data dengan menggunakan teknik uji-t (t-test ), yang dihitung menggunakan bantuan SPSS 17.0 for Windows, menunjukkan hasil $\mathrm{t}_{\text {hitung }}=14.492>\mathrm{t}_{\text {tabel }}=2.132$ dan $\rho=$ 0,$000 ; \rho<0,05$. Hasil ini menunjukkan bahwa ada perbedaan tingkat stres akademik pada mahasiswa sebelum mendapat perlakuan berupa pelatihan tadabbur surat Al-Insyirah dengan sesudah mendapatkan perlakuan. Artinya bahwa sebelum mendapatkan pelatihan tadabbur surat Al-Insyirah tingkat stres 
akademik mahasiswa cenderung pada tingkat tinggi yaitu $68.75 \%$ (11 mahasiswa), kemudian pada tingkat stres akademik sedang yaitu $31.25 \%$ (5 mahasiswa), tingkat stres akademik rendah $0 \%$. Sedangakn setelah mengikuti pelatihan tadabbur surat Al-Insyirah tingkat stres akademik mahasiswa mengalami enurunan yaitu pada klasifikasi tingkat stres sedang sebesar $56.25 \%$ (9 mahasiswa) dan klasifikasi tingkat stres rendah $43.75 \%$ (7 mahasiswa), sedangkan tingkat stres akademik tinggi yaitu $0 \%$.

Untuk mengetahui besar pengaruh pelatihan tadabbur surat Al-Insyirah dalam menurunkan tingkat stres akademik pada mahasiswa yaitu dapat dilihat dari hasil penghitungan univarite. Hasil penghitungan univariate menunjukkan hasil bahwa $\mathrm{F}_{\text {hitung }}=$ $179.917>\mathrm{F}_{\text {tabel }}=4.49(\mathrm{df}=1 \mathrm{~N}=16 ; \alpha=0.05)$ dengan sig / $\rho=0.000 ; \rho<0.05$ maka ha diterima, sehingga dapat disimpulkan bahwa ada pengaruh yang sangat besar pelatihan tadabbur Surat Al-Insyirah untuk menurunkan tingkat stres akademik. Sedangkan besar pengaruh partial eta squared $R^{2}=0.857$, yang artinya bahwa besar pengaruh pelatihan tadabbur surat Al-Insyirah dalam menurunkan tingkat stres akademik pada mahasiswa putri mustawa Tsani adalah sebesar $85.7 \%$. Dengan demikian perlakuan berupa pelatihan tadabbur surat Al-Insyirah dapat menurunkan tingkat stres akademik pada mahasiswa Ma'had Umar Bin Al-Khatab Universitas Muhammadiyah Sidoarjo.

Hasil penelitian diatas memperkuat kesimpulan Jauzi dalam Hayyi (2012), mengatakan bahwa Al-Qur'an merupakan pengobatan yang sempurna bagi segala penyakit fisik dan jiwa, penyakit dunia dan akhirat. Al-Qur'an akan menjadi obat bagi individu ketika individu tersebut mau berobat dengan Al-Qur'an secara benar dan dilandasi keimanan, menerima Al-Qur'an secara utuh, mempercayainya dengan pasti, dapat mengambil hikmah dan pelajaran dari Al-Quran dan dapat mengamalkan dalam kehidupan sehari-hari. Sebagaimana firman Allah yang terdapat dalam surat Al-Ahqaaf: 13
: "Sesungguhnya orang-orang yang mengatakan "Tuhan kami ialah Allah", kemudian mereka tetap istiqomah, maka tidak ada kekhawatiran bagi mereka dan mereka tidak pula berduka cita".

Pelatihan tadabbur surat Al-Insyirah membantu mahasiswa mereduksi pikiranpikiran negatif akibat stres seperti cemas, khawatir, takut, kecewa, sensitif, putus asa, tidak percaya diri, dengan pikiran-pikiran yang positif dari aspek-aspek psikologis yang terkandung dalam surat Al-Insyirah yaitu optimis, sabar, ketenangan jiwa, tawakal dan percaya pada kemapuan diri. Pikiran-pikiran positif ini akan membantu mahasiswa lebih adaptif dalam menghadapi stres. Hal ini sesuai dengan pendapat Hasan (2008) bahwa berpikir postif dapat meningkatkan kesehatan fisik dan psikologis, memberikan korelasi positif terhadap proses penyembuhan penyakit dan kesejahteraan (Hasan, 2008). Selain itu berpikir positif juga merupakan bagian penting dari manajemen stres yang efektif. Berfikir positif dapat meningkatkan hormon endokrin oleh kelenjar otak untuk mengimbangi hormon adrenalin dan kortisol yang berlimpah jumlahnya pada saat individu mengalami stres (Smet, 1994).

Visualisai dalam pelatihan tadabbur surat Al-Insyirah ini bertujuan agar peserta dapat menggambarkan dirinya adalah inividu yang optimis, sabar, memiliki banyak kelebihan, tidak putus asa, selalu tawakal dan sabar apabila dihadapkan pada tekanan dan kesulitan dalam menjalani aktivitas akademik. Individu juga dituntun untuk melepaskan segala emosi-emosi yang terpendam yang tidak bisa dikeluarkan. Pelepasan emosi ini disebut juga dengan katarsis. Katarsis dapat memancing emsoi individu. Emosi yang kuat dapat memancing air mata, secara fisiologis gen dalam tubuhlah yang menyebabkan hal ini terjadi. Menangis sejadijadinya menjadi sebuah pelepasan yang membuat individu merasa lebih baik (Hawari, 2005). Ketika pikiran individu sudah dapat menghayati aspek-aspek psikologi surat AlInsyirah dan individu sudah dapat membayangkan dirinya secara positif, maka 
individu akan lebih dapat bersyukur dan optimis dalam menghadapi kesulitan akademik.

Kebahagiaan, keceriaan, rasa syukur, sabar, do'a, optimis, ketenangan jiwa (faktor psikologis dan spiritualitas) dapat mengaktifkan gen-gen yang baik dan me-nonaktifkan gen-gen buruk. Dengan penekanan pada ayat 5 dan 6 surat Al-Insyirah yaitu "Maka sesungguhnya beserta kesulitan itu ada kemudahan (5), Ayat ke-6 : Sesungguhnya beserta kesulitan itu ada kemudahan.Individu akan selalu berfikir positif dalam menghadapi kesulitan, karena individu yakin bahwa kesulitan tidak kekal, dan pasti akan ada pertolongan dari Allah selama individu sabar dan tawakal hanya kepada Allah. Kesembuhan menggunakan Al-Qur'an dapat dilakukan dengan membaca, berdekatan dengannya, dan mendengarkannya, sebagaimana yang disampaikan oleh Ansyah (2017) bahwa Al-Fatihah bisa digunakan sebagai konsep psikologi dan menggunakannya sebagai pendekatan konseling yang disebut dengan konseling berdasarkan psikologi alFatihah. Dengan membaca saja Al-Quran sudah mempunyai efek yang menyembuhkan, apalagi kemudian ditadabburi dengan visualisasi.

Hal ini sejalan dengan pendapat Mustamir (2007) bahwa membaca Al-Quran dapat memperkuat pemaknaan ayat-ayat Al-Quran karena impulsnya datang melalui korteks penglihatan dan pendengaran. Penguatan makna tersebut akan meningkatkan kualitas emosi positif individu. Hasil Penelitian Gallup dan Lindsay (1999), menunjukkan bahwa orang yang beragama memiliki nilai lebih tinggi dalam skor kesehatan dan kesejahteraan secara umum dibandingkan dengan orang-orang yang tidak atau kurang religius. Agama menjadi sarana meditasi dan menyediakan mekanisme untuk mengatasi masalah hidup seperti membaca kitab suci, berdoa dan menjalankan ritual keagamaan.

Namun demikian dari evaluasi yang dilakukan peneliti baik pada setiap akhir pertemuan maupun dari evaluasi secara keseluruhan pada pertemuan terakhir (IV) terdapat beberapa keterbatasan, pertama; wilayah generalisasi dari penelitian ini hanya terbatas pada mahasiswa Mah'ad Umar Bin AlKahatab. Apakah pelatihan ini juga efektif untuk menurunkan tingkat stres pada mahasiswa umum yang belum mengerti tentang tafsir Al-Quran, tidak mengerti Bahasa Arab masih diperlukan penelitian lebih lanjut. Kedua; peneliti tidak melakukan follow up, sehingga belum dapat diketahui konsistensi dari hasil penelitian tersebut pada sabjek setelah pelatihan berakhir. Apakah hasil pelatihan tadabbur surat Al-Insyirah dapat terus efektif setelah jangka waktu 1 bulan atau satu tahun setelah pelatihan. Ketiga; variabel terikat pada penelitian ini adalah tingkat stres akademik, apakah pelatihan tadabbur surat Al-Insyirah ini juga dapat digunakan untuk menurunkan kecemasan, depresi, trauma dan problem-problem psikologis yang lain. Atau apakah pelatihan tadabbur surat Al-insyirah ini dapat digunakan untuk meningkatkan variabel-variabel psikologis yang lain seperti meningkatkan self esteem atau meningkatkan motivasi kerja, motivasi berprestasi, maka perlu penelitian lebih lanjut, sehingga pelatihan tadabbur surat Al-Insyirah ini dapat digunakan sebagai intervensi alternatif untuk mengatasi masalahmasalah psikologis pada masyarakat yang lebih luas.

\section{Simpulan}

Hasil penelitian ini menunjukkan bahwa pelatihan tadbbur surat Al-Insyirah mampu menurunkan tingkat stres akademik pada mahasiswa. Artinya bahwa pelatihan tadabbur surat Al-Insyirah dapat digunakan sebagai tindakan intervensi untuk mengatasi permasalahan stres akademik yang dialami oleh mahasiswa. Hal ini menunjukkan bahwa penghayatan terhadap al-Qur'an, dalam hal ini adalah surat al-Insyirah bisa digunakan sebagai penekatan dalam psikoterapi terhadap gangguan psikologi.

JPIB : Jurnal Psikologi Islam dan Budaya, April 2019, Vol.2 No.1 


\section{Referensi}

Agolla, J.E., \& Ongari, H. (2009). An assasment of academic stres among undergraduates students. Academic journals, educational research and review . Vol 4 (2), pp. 063-070.

Ansyah, E. H., \& Hadi, C. (2017). PSIKOLOGI AL-FATIHAH: Solusi untuk Mencapai Kebahagiaan yang Sebenarnya. Jurnal Psikologi Islam, 4(2), 107-120.

Azzahra, A. (2012). Efektifitas Pelatihan Pemaknaan Surat Al-Insyirah Untuk Mengurangi Stres Mahasiswa Yang Sedang Mengerjakan Skripsi. Skripsi. Universitas Islam Negeri Sunan Kalijaga Yogyakarta. Publikasi Online: http://www.bab\%20I\%2c\%20v\%2c\%20da ftar\%pustaka.pdf. Diakses pada tanggal 12 Februari 2012.

Gallup, G. Jr. \& Lindsay, D.M. (1999). Surveying The Religious Landscape : Trends In U.S. Belief. Journal of Religion and Spirituality. Vol (6) p.274-291. Harrisburg, PA : Morehouse.

Goff, A.M. (2011). Stressor, Academic Permormance, And Learned Resourcefulness In Baccalaureate Nursing Students. International Juornal Of Nursing Education Scholarship. Vol 65 (10), 20062056.

Giordano, F. J., \& Giordano, F. J. (2005). failure Find the latest version: Review series Oxygen , oxidative stress, hypoxia, and heart failure. The Journal of Clinical Investigation, 115(3), 500-508. https://doi.org/10.1172/JCI200524408.500

Govaerst, S. \& Gregoire, J. (2004). Stressful academic situstions : Study on appraisil variables in adolescence. British Journal of Clinical Psycology, 54, 261-271.

Hasan, A. B. P. (2008). Pengantar Psikologi Kesehatan Islami. Jakarta: PT.Rajagrafindo Persada.

Hawari, D. (2005). Dimensi Religi dalam Praktek Psikiatri dan Psikologi.
Jakarta:Fakultas Kedokteran Universitas Indonesia.

Hayyi, A. (2012). Fiqh al Islam wa Adillatuh. Jakarta: Cakrawala.

Juriyah, S. (2004). Sikap Optimis Dan Penanggulangan Stres Dalam Perspektif Al-Quran (Kajian Pedagogis Terhadap Q.S.Al-Insyirah : 5-8). Skripsi. Publikasi Online :http://jtptiain-gdl-s12004sitijuriya-1550-coverdll-1-pdf. Institut Agama Islam Negeri Walisongo Semarang. Diakses pada tanggal 3 Januari 2014.

Muhammad, A. (2011). Melakukan Hipnoterapi Agar Daya Ingat Anda Sekuat Cakram. Cetakan II. Jogjakarta : Diva Press.

Murphy, J. \& Kandil, M. (2003). World Level Stress Patterns In The Academic Word List. Journal Departement of linguistik and English as a second language, Georgia state University Atlanta, Vol 32 (2) p. 6171.

Mustamir. (2007). Sembuh dan Sehat dengan Mukjizat Al-Qur'an. Yogyakarta : Lingkaran.

Najati, M. U. (2005). Psikologi dalam al-quran. Bandung: Pustaka Setia.

Nandamuriand Gowthami. (2010). Sources Of Academic Stress -A Study On Management Studen Ts. Itm Business School; Hunter Road, Warangal-506001. A.P. India. Lecturer, ITM Business School; Hunter Road,Warangal -506001. A.P. India. p.12-31.

Potter, P., \& Perry, A. (2005). Buku ajar fundamental keperawatan: konsep, proses, dan praktik. Jakarta: Egc.

Purwoko, S. B. (2012). Psikologi Islami : Teori dan Penelitian (edisi kedua). Saktiyono WordPress.

Rathakrishnan, E. (2009). Experimental Studies on the Limiting Tab. AIAA Journal, 47(10), 2475-2485. https://doi.org/10.2514/1.43790

Robotham, D. (2008). Stres Among Higher Education Students : Towards A Research 
Agenda. Springer Science and Business Media B.V Journal Vol 56 p. 735-746.

Sabry, W. M., \& Vohra, A. (2013). Role of Islam in the management of Psychiatric disorders. Indian Journal of Psychiatry, 55 (Suppl 2), S205-S214. http://doi.org/10.4103/0019-5545.105534

Safaria, T. dan Saputra. (2007), Stress Ditinjau Dari Active Coping, Avoidance Coping dan Negativ Coping.Disampaikan padaKonferensi StressNasional Managemen, Fakultas Psikologis Ahmad Dahlan Bandung. Publikasi online http://journal.uad.ac.id/index.php/HUMAN ITAS/article/view/720. Diakses pada tanggal 15 Desember 2014.

Smet, B. (1994). Psikologi Kesehatan. Jakarta:PT Grasindo.

Widianti, E. (2007). Remaja Dan Permasalahannya: Bahaya Merokok, Penyimpangan Seks Pada Remaja, Bahaya Penyalahgunaan Minuman Keras Dan Narkoba. Artikel Bahaya Kenakalan Remaja. Pubilkasi Online Diakses pada tanggal 2 Januari 2014 dari : htpp://prov.bkkbn.go.id..
Wulandari, R. P. (2012). Hubungan Tingkat Stres Dengan Gangguan Tidur Pada Mahasiswa Skripsi di Salah Satu Fakultas Rumpun Science-Technology Universitas Indonesia.Skripsi. PublikasiOnline: http://www.digilib.ui.ac.id/file/abstrack20313206.pdf. Diakses pada tanggal 12 Desember 2013.

Yusuf, H. A. (2015). India Akan Kalahkan Indonesia Soal Pemeluk Islam. Diakses pada tanggal 29 Maret 2016 dari https://m.tempo.co/read/news/2015/04/05/ 116655435/india-akan-kalahkanindonesia-soal-pemeluk-islam 